\title{
Modulation of Transforming Growth Factor $\beta$ Receptor Levels on Microvascular Endothelial Cells during In Vitro Angiogenesis
}

\author{
Sabita Sankar, Negar Mahooti-Brooks, Linda Bensen, Thomas L. McCarthy, ${ }^{\star}$ Michael Centrella, ${ }^{\star}$ and Joseph A. Madri \\ Departments of Pathology and *Plastic Surgery, Yale University School of Medicine, New Haven, Connecticut 06510
}

\begin{abstract}
Microvascular endothelial cells (RFCs) cultured in twodimensional (2D) cultures proliferate rapidly and exhibit an undifferentiated phenotype. Addition of transforming growth factor $\beta 1$ (TGF $\beta 1$ ) increases fibronectin expression and inhibits proliferation. RFCs cultured in three-dimensional (3D) type I collagen gels proliferate slowly and are refractory to the anti-proliferative effects of TGF $\beta 1$. TGF $\beta 1$ promotes tube formation in $3 D$ cultures. TGF $\beta 1$ increases fibronectin expression and urokinase plasminogen activator (uPA) activity and plasminogen activator inhibitor-1 (PAI-1) levels in 3D cultures. Since the TGF $\beta$ type I and II receptors have been reported to regulate different activities induced by TGF $\beta 1$, we compared the TGF $\beta$ receptor profiles on cells in $2 \mathrm{D}$ and $3 \mathrm{D}$ cultures. RFCs in $3 \mathrm{D}$ cultures exhibited a significant loss of cell surface type II receptor compared with cells in $2 \mathrm{D}$ cultures. The inhibitory effect of TGF $\beta 1$ on proliferation is suppressed in transfected 2D cultures expressing a truncated form of the type II receptor, while its stimulatory effect on fibronectin production is reduced in both $2 \mathrm{D}$ and $3 \mathrm{D}$ transfected cultures expressing a truncated form of the type $I$ receptor. These data suggest that the type II receptor mediates the antiproliferative effect of TGF $\beta 1$ while the type I receptor mediates the matrix response of RFCs to TGF $\beta 1$ and demonstrate that changes in the matrix environment can modulate the surface expression of TGF $\beta$ receptors, altering the responsiveness of RFCs to TGF $\beta 1$. (J. Clin. Invest. 1996. 97:1436-1446.) Key words: transforming growth factor $\beta$ receptors $\bullet$ proliferation - fibronectin • angiogenesis $\bullet$ microvascular endothelial cells
\end{abstract}

\section{Introduction}

Angiogenesis, the formation of new vessels, occurs during normal development and in response to injury. The ability of a tumor to elicit angiogenesis also appears to be a critical step in cancer and may regulate its progression. The microvessel endothelial cell is the principle cell type involved in the process of angiogenesis $(1,2)$. Angiogenesis is modulated by soluble growth factors, and the existing and newly-formed extracellular matrix (ECM) (3-8). Although intensively studied, the in-

Address correspondence to Dr. Joseph A. Madri, Department of Pathology, Yale University School of Medicine, 310 Cedar Street, New Haven, CT 06510. Phone: 203-785-2763; FAX: 203-785-7303.

Received for publication 7 November 1995 and accepted in revised form 19 January 1996.

J. Clin. Invest.

(C) The American Society for Clinical Investigation, Inc.

0021-9738/96/03/1436/11 \$2.00

Volume 97, Number 6, March 1996, 1436-1446 teraction of endothelial cells with the ECM during angiogenesis is still incompletely understood (2).

Investigators have devised several in vitro culture systems to mimic angiogenesis. These include culturing capillary endothelial cells in fibrin clots (9), collagen gels (10-12), or other ECM proteins $(13,14)$. The in vitro angiogenic process, which usually takes several days to weeks, can be enhanced by the addition of soluble factors such as TGF $\beta$ and by changing the composition of the $\operatorname{ECM}(2,10,11)$.

Transforming growth factors $\beta$ belong to a family of multifunctional peptides of which five isoforms termed TGF $\beta 1$, TGF $\beta 2$, TGF 33 , TGF $\beta 1.2$, and TGF $\beta 1.3$ have been identified in mammals (15-18). TGF $\beta$ is multipotent with marked effects on cell proliferation, differentiation, adhesion, migration, ECM production and other activities $(16,17)$. TGF $\beta$ affects the cell cycle and is also a potent inducer of many components of the ECM including collagen, fibronectin and cell surface integrins $(16,17)$. TGF $\beta 1$ also decreases the synthesis of enzymes such as collagenases $(19,20)$ and transin/stromelysin $(21)$ that catalyse degradation of matrix components, while concomitantly increasing the levels of protease inhibitors such as plasminogen activator inhibitor $(22,23)$. When injected locally, TGF $\beta$ induces the formation of granulation tissue and angiogenesis (7) and accelerates wound healing (24). The stimulatory effect of TGF $\beta$ on angiogenesis in vivo may be due to cellular migration and extracellular deposition $(7,25)$. However, the mechanism of the angiogenic effects of TGF $\beta$ in vivo are controversial since TGF $\beta$ is a potent inhibitor of proliferation of cultured endothelial cells in some circumstances $(7,26,27)$.

TGF $\beta$ s exert their effects on cells via binding to specific receptors (28-30), a number of which have been identified. These include three distinct classes denoted receptors type I (53 kD), type II (65 kD), and type III (or betaglycan), which is a $300-\mathrm{kD}$ proteoglycan with a $120-\mathrm{kD}$ core protein $(31,32)$. The TGF $\beta$ type I and type II receptors belong to a growing family of transmembrane serine/threonine kinases which also include the activin receptor and the daf- 1 protein $(33,34)$. Current evidence supports the concept that receptors type I and II, together, are directly involved in receptor signal transduction (31, 32, 35-37), although these findings may not be universal (38-40).

To study the complex process of angiogenesis and microvascular differentiation in vitro, we have used cultures of microvascular endothelial cells from the rat epididymal fat pad (RFCs) grown on type I collagen-coated plates, for twodimensional (2D) cultures, and within type I collagen gels for three-dimensional (3D) cultures (10-12). RFCs in 2D cultures proliferate rapidly. Addition of TGF $\beta 1$ inhibits the proliferation of these cells and induces $\alpha$-smooth muscle actin mRNA and protein. Cultured microvascular endothelial cells in 2D cultures also express platelet derived growth factor (PDGF) $\alpha$ and $\beta$ receptors and respond differently to PDGF isoforms (41). When microvessel endothelial cells are dispersed and cultured in 3D type I collagen gels, their behavior is quite distinct from that observed in 2D culture systems. Specifically, cells in 
3D cultures proliferate slowly $(11,42)$ and PDGF isoforms are not mitogenic, apparently due to the progressive loss of cell surface PDGF $\alpha$ and $\beta$ receptors (43). TGF $\beta 1$ does not further reduce the proliferative rate of the these cells but induces a rapid and dramatic morphogenic response, wherein the cells organize into multicellular tube-like aggregates with discernible lumina, a response that simulates angiogenesis in vitro. The cells also no longer express $\alpha$-smooth muscle actin mRNA and protein. These data are consistent with the concept that the composition and organization of the surrounding matrix modulate endothelial cell phenotype by affecting cell surface receptor expression, matrix biosynthesis as well as cytoskeletal organization and composition (2).

Our working hypothesis is that microvascular endothelial cells cultured in 2D cultures mimic the cells at the tip of an angiogenic sprout in terms of their high proliferative rates, whereas microvascular endothelial cells in $3 \mathrm{D}$ cultures mimic the cells distal to the sprout which are more differentiated (1, 2, 42).

Hence the aim of these current studies is to determine the role TGF $\beta 1$ plays in promoting in vitro angiogenesis and to understand the differences in TGF $\beta 1$ responsiveness of RFCs in $2 \mathrm{D}$ versus $3 \mathrm{D}$ cultures. Such studies could potentially explain the differences in the angiogenic effects of TGF 1 in vivo during different phases of vessel development. We now report that TGF $\beta 1$ upregulates the expression and protein levels of fibronectin and the activities of urokinase plasminogen activator and plasminogen activator inhibitor-1 in 3D cultures. Furthermore, we provide evidence that the loss of the anti-proliferative effect of TGF $\beta 1$ in 3D cultures is due to a significant decrease in surface expression of TGF $\beta$ type II receptor.

\section{Methods}

Cell culture. Capillary endothelial cells (RFCs) were isolated and cultured from Sprague-Dawley rat epididymal fat pads as described by Madri and Williams (10). RFCs were passaged and grown on $1.5 \%$ gelatin-coated tissue culture plates in Dulbecco's Modified Eagle's Medium (DME; GIBCO BRL, Grand Island, NY) mixed with 4:1 sterile-filtered conditioned bovine aortic endothelial cell media as described (10) containing 10\% heat-inactivated fetal calf serum (FCS; GIBCO BRL). Two-dimensional cultures of RFCs were grown on acid-soluble calf dermis collagen type I-coated tissue culture plates. Three-dimensional RFC cultures were made within gels composed of acid-soluble calf dermis collagen type I (11). Briefly, purified collagen was solubilized in $10 \mathrm{mM}$ acetic acid at a concentration of $2.5 \mathrm{mg} / \mathrm{ml}$ and stored at $4^{\circ} \mathrm{C}$. A measured amount of the collagen with 1/10th the volume of Earle's salt was neutralized with sterile $1 \mathrm{M} \mathrm{NaOH}$ and the solution kept on ice. Cultured RFCs, resuspended in DME, were added to the collagen preparation to achieve a concentration of $10^{6}$ cells $/ \mathrm{ml}$ of collagen. Aliquots of $50 \mu \mathrm{l}$ of this suspension were placed in $100 \mathrm{~mm}$-diameter bacteriological petri dishes (Falcon Labware, Oxnard, CA), incubated for $10 \mathrm{~min}$ at $37^{\circ} \mathrm{C}$ in a humidified incubator containing $8 \% \mathrm{CO}_{2}$ to allow polymerization, after which media with and without TGF $\beta 1$ were added to the plates.

Transfection. For transfection experiments, cells were plated on $60 \mathrm{~mm}$ dishes at $80 \%$ confluency. The cells were transfected with 10 $\mu \mathrm{g}$ of plasmid DNA and $25 \mu \mathrm{g}$ of Lipofectamine ${ }^{\mathrm{TM}}$ (GIBCO BRL) per plate and incubated with serum-free media (GIBCO BRL) for several hours before growth media was added. Plasmids used for the transfection were pcDNA3 containing the neomycin resistance marker (Invitrogen, San Diego, CA), TYPEIIRT, a eukaryotic expression vector, $\mathrm{pRK} 5$, containing the truncated form of the TGF $\beta$ type II receptor (a gift from R. Derynck, University of San Francisco,
CA) (39), an expression vector, pSV7d, containing the type I receptor cDNA, ALK5 (a gift from P. ten Dijke and K. Miyazono, Ludwig Institute of Cancer Research, Sweden) (33) and a truncated form of the cDNA, ALK5, termed ALK5D. To generate ALK5D, pSV7d containing ALK5 cDNA was digested with $\mathrm{XbaI}$ and BamHI, and the larger 3.1-kb fragment, containing ALK5 cDNA minus $1.5 \mathrm{~kb}$ of the $3^{\prime}$ end of the ALK5 cDNA, was purified and religated. Selection for transfectants with $400 \mu \mathrm{g} / \mathrm{ml} \mathrm{G} 418$ (Geneticin, GIBCO BRL), was carried out $48 \mathrm{~h}$ after transfection. Neomycin-resistant colonies were isolated in cloning rings and expanded before analysis for surface expression of the receptors by cross-linking with iodinated TGF $\beta 1$.

The vector used for transfection of the type III receptor in the antisense orientation was identical to the one used previously (44). Briefly the HindIII fragment of the rat type III receptor cDNA (R3OFF) was subcloned into pcDNA I NEO (Invitrogen, San Diego, CA) which is under the control of the cytomegalovirus transcriptional promoter and the SV40 origin of replication. In addition, two other constructs were generated by subcloning a 3.9-kb EcoRI fragment from the rat type III receptor cDNA (a gift from J. Massague, Memorial Sloan Kettering Cancer Center, NY) into the pSV7d expression vector which is under the control of the SV40 transcriptional promoter. The orientation of the EcoRI fragment was checked by restriction digests with AflIII and SalI. The rat type III receptor cDNA was subcloned into pSV7d in the antisense orientation (TYPEIIIASRT). A control vector pcDNA3 (Invitrogen, San Diego, CA) containing the neomycin resistance marker was cotransfected into the cells along with the type III receptor cDNA subcloned into the pSV7d (44).

Specifically, four clones of transfectants containing the vector alone, six clones of transfectants containing ALK5, six clones of transfectants containing ALK5D, three clones of transfectants containing TYPEIIRT and three clones of transfectants containing the type III receptor in the antisense orientation were selected and characterized. Three clones each of transfectants containing the vector alone (V2, V4, V8) or ALK5D (ALK5D1, ALK5D3, and ALK5D4) were selected for further analysis to determine TGF $\beta 1$ responsiveness. Similarly, two clones each of the transfectants containing ALK5 (ALK54 and ALK58) or TYPEIIRT (typeIIRT1 and typeIIRT3) and one clone of the transfectants containing TYPEIIIASRT selected for further analysis to determine TGF $\beta 1$ and TGF $\beta 2$ responsiveness. The transfectants grown for several passages maintained their cell surface TGF $\beta$ receptor profiles as determined by cross-linking experiments with iodinated TGF $\beta$.

Materials. Human transforming-growth factor beta (TGF $\beta 1)$ and TGF $\beta 2$ were purchased from R \& D Systems Inc., Minneapolis. Iodinated TGF $\beta 1$ was obtained from Biomedical Technologies Inc. (Stoughton, MA). Bovine type I collagen was isolated and purified as described (44-46). Antisera directed against the Type I (V22) and Type II (L21) TGF $\beta$ receptors were purchased from Santa Cruz Biotechnology, Inc., Santa Cruz, CA. Tissue culture plates were coated with type I collagen at a concentration of $12.5 \mu \mathrm{g} / \mathrm{ml}$.

Proliferation assays. Collagen type I coated bacteriological culture dishes were washed in phosphate buffered saline (PBS) before the addition of cell suspension $(1 \times 104$ cells $/$ dish $)$. The cells were allowed to attach to the coated dishes for several hours. At this point, fresh medium with and without TGF $\beta 1$ or TGF $\beta 2$ was added to the cultures. The medium and factors were replaced once again on the third day. Cell numbers were determined by lifting the cells off the culture dishes with trypsin/EDTA (ethylenediaminetetracetic acid) and counting quadruplicate samples using a Coulter counter (Coulter Electronics Inc., Hialeah, FL). The mean number of cells per dish for each condition was then calculated. To assess the proliferation rates in $3 \mathrm{D}$ collagen cultures, the cultures were rinsed five times with PBS, and five collagen droplets were placed into $6 \mathrm{ml}$ of $1 \mathrm{mg} / \mathrm{ml}$ collagenase (Cooper Biomedical, $137 \mathrm{U} / \mathrm{mg}$ ), and incubated for $45 \mathrm{~min}$ in a $37^{\circ} \mathrm{C}$ shaking water bath. Subsequently the cells were pelleted and resuspended in $3 \mathrm{ml}$ of media. $1 \mathrm{ml}$ of the resuspended pellet was added to $9 \mathrm{ml}$ of Isoton buffer and counted using a Coulter Counter (43). 
Cell extract preparation. Cell extracts were obtained after washing the cells three times with phosphate-buffered saline (PBS) and then scraping into $0.05 \%$ Triton $\mathrm{X}-100,120 \mathrm{mM}$ Tris-HCl, $\mathrm{pH} 8.7$.

Zymography. Cell extracts were obtained as described above, normalized for cell protein using the bicinchonic acid assay (Pierce Chemical Co., Rockford, IL) and $10 \mu \mathrm{g}$ of cell extract was electrophoresed in a $10 \%$ polyacrylamide gel. The gel was then washed in $2.5 \%$ Triton X-100 for $1 \mathrm{~h}$ followed by two $20 \mathrm{~min}$ washes in water. The gel was then overlaid on a thin agar gel with final concentrations of $4 \%$ nonfat milk, $0.1 \mathrm{M}$ Tris- $\mathrm{HCl} \mathrm{pH} 8.0,8 \mu \mathrm{g} / \mathrm{ml}$ plasminogen, $1.25 \%$ agar and photographed with darkfield illumination (48). For reverse zymography the gel and overlay were incubated at $37^{\circ} \mathrm{C}$ until the generated plasmin had diffused throughout the entire gel and all the casein was degraded except where PAI-1 was located. The gels were then examined and photographed with darkfield illumination (48).

Assay for fibronectin synthesis. Equal numbers of RFCs plated in 2D and 3D cultures were starved in methionine-free media for $2 \mathrm{~h}$. The cells were subsequently labeled overnight with $50 \mu \mathrm{Ci}\left[{ }^{35} \mathrm{~S}\right] \mathrm{me}-$ thionine (Amersham Corp, Arlington Heights, IL) per $\mathrm{ml}$ of media containing $19 \mu \mathrm{M}$ cold methionine and supplemented with $10 \%$ dialyzed fetal calf serum. The secreted $\left[{ }^{35} \mathrm{~S}\right]$ methionine-labeled fibronectin was affinity-purified by incubating with gelatin-Sepharose (Pharmacia-LKB, Piscataway, NJ). Briefly, equal volumes of the cell media $(500 \mu \mathrm{l})$ were incubated with $100 \mu \mathrm{l}$ of gelatin-Sepharose with endover-end mixing for two hours. The fibronectin bound to gelatinSepharose was spun down and washed several times with Tris-buffered saline (TBS) and eluted with gel-loading buffer before boiling and running the samples on a $6 \%$ polyacrylamide gel. The gel was subsequently fixed in destain solution (10\% methanol; $10 \%$ acetic acid), and washed in deionized water for $15 \mathrm{~min}$ before incubating with freshly-prepared $1 \mathrm{M}$ sodium salicylate for 30-45 min. The gel was dried and exposed to film overnight in a $-80^{\circ} \mathrm{C}$ freezer before developing by autoradiography. Densitometry was assessed using a Molecular Dynamics densitometer equipped with Image Quant software.

Receptor binding autoradiography assay The assay was a modification of our earlier studies $(38,49,50)$. Briefly, confluent monolayers grown on $35 \mathrm{~mm}, 1.5 \%$ gelatin-coated tissue culture plates or cells grown in three-dimensional collagen gels were washed with cold binding buffer (DME, $25 \mathrm{mM}$ Hepes, pH 7.4, 0.1\% BSA) and then allowed to equilibrate with binding buffer for $30 \mathrm{~min}$ at $4^{\circ} \mathrm{C}$ on a rotating platform. The buffer was aspirated and $250 \mu \mathrm{l}$ of ice-cold binding buffer containing $100 \mathrm{pM}{ }^{125}$ I-labeled TGF $\beta 1$ (4000-5500 Ci/mmol) was added to each culture and incubated on a rotatory platform at $4^{\circ} \mathrm{C}$ for $3 \mathrm{~h}$. After washing at $4^{\circ} \mathrm{C}$, ice-cold binding buffer lacking BSA was added to the plates and the samples were cross-linked by the addition of disuccinimidyl suberate (DSS; Pierce Chem. Co., Rockford, IL) at a final concentration of $0.5 \mathrm{mM}$. The plates were swirled immediately after addition of DSS to minimize precipitation of DSS. After $15 \mathrm{~min}$, the cells were washed several times with binding buffer before lysis with $150 \mu \mathrm{l}$ of Laemmli loading buffer containing $30 \mu \mathrm{l}$ of 1 $\mathrm{mM}$ dithiothreitol (DTT). The cell lysate was boiled and electrophoresed according to Laemmli, 1970 (51) on 5-10\% linear gradient gels. The gels were fixed, dried and exposed to Amersham Hyperfilm ${ }^{\mathrm{TM}} \mathrm{MP}$ at $-80^{\circ} \mathrm{C}$. The films were developed using a Kodak X-OMat M20 Processor (Eastman Kodak Co., Rochester, NY). Densitometry was assessed using a Molecular Dynamics densitometer equipped with Image Quant software.

Western blotting assay. Western blots utilizing polyclonal rabbit antisera directed against TGF $\beta$ receptor Type I (V22) and type II (L21) were performed according to the vendor's protocols (Santa Cruz Biotechnology Inc., Santa Cruz, CA). Cells grown in twodimensional and three-dimensional culture for one and $5 \mathrm{~d}$ were lysed in and extracted with RIPA buffer $(0.05 \%$ Triton X-100 and $120 \mathrm{mM}$ Tris $\mathrm{HCl} \mathrm{pH}$ 8.7). Cell extracts were normalized for total protein using the bicinchonic acid assay (Pierce) and electrophoresed through a $5-15 \%$ gradient reducing polyacrylamide gel. Proteins were trans- ferred to a nitrocellulose membrane (Schleicher and Schuell, Keene, $\mathrm{NH}$ ), blocked with $8 \%$ nonfat milk in PBS and incubated with rabbit anti-TGF $\beta$ receptor type I and type II antisera (Santa Cruz Biotechnology, Inc.) at a concentration of $1 \mu \mathrm{g} / \mathrm{ml}$ and then goat anti-mouse secondary antibody conjugated to horseradish peroxidase (Promega, Madison, WI) at 1:10,000 dilution. The blot was developed using the enhanced chemiluminescence method (Amersham Corp, Arlington Heights, IL) with Hyperfilm ${ }^{\mathrm{TM}}$-MP. Bands were quantitated using a Molecular Dynamics densitometer (Molecular Dynamics Scanner, Sunnyvale, California).

Statistical analysis. Data were analyzed in multiple samples after multiple determinations and are expressed as means \pm SE. Significance was determined using the students' $t$ test method in the Systat Software Package (Systat Inc., Evanston, IL) run on a Macintosh 650 Quadra computer. Statistical significance was assumed for $P<0.05$.

\section{Results}

We have previously characterized the angiogenic effect of TGF $\beta 1$ on microvascular endothelial cells in 3D cultures (42, 49). TGF $\beta 1$ increases the formation of multicellular aggregates after $24 \mathrm{~h}$ of treatment compared with untreated cells. After $5 \mathrm{~d}$ of treatment, cells in control cultures exhibit minimal areas of aggregates consisting of several cells forming rudimentary tube-like structures while cells in TGFß1-treated cultures exhibit increased aggregate formation, cell-cell contact with junctional complexes and marked contraction of the gels. TGF $\beta 1$-treated endothelial cell cultures showed extensive lumen-like formation, mimicking in vivo capillary bed structures. Thus to determine the effects of TGF $\beta 1$ on microvascular endothelial cells in $2 \mathrm{D}$ versus $3 \mathrm{D}$ cultures, we chose two time points $(24 \mathrm{~h}$ and $5 \mathrm{~d})$ to investigate different stages of the angiogenic process in $3 \mathrm{D}$ cultures and to compare the analogous effects of TGF $\beta 1$ on microvascular endothelial cells in 2D cultures.

TGF 31 inhibits proliferation of microvessel endothelial cells in $2 D$ cultures but not in $3 D$ cultures. Proliferation assays were carried out on RFCs cultured for $5 \mathrm{~d}$ in $2 \mathrm{D}$ and $3 \mathrm{D}$ conditions in the absence or presence of $0.5 \mathrm{ng} / \mathrm{ml}$ TGF $\beta 1$. In 2D cultures, TGF $\beta 1$ inhibited the proliferation of RFCs by $37 \pm 3 \%$ compared with control cells $(P<0.00001)$. It has been previously reported that TGF $\beta 1$ causes a potent angiogenic response in vivo and yet profoundly inhibits proliferation in a 2-D monolayer in vitro $(7,11)$. In 3D cultures however, there was no difference between the number of cells in the TGFB1-treated and control untreated $3 \mathrm{D}$ cultures $-7 \pm 4 \%(P=0.07)$, confirming our earlier findings (49).

TGF $\beta 1$ modulates fibronectin protein levels in $2 D$ and $3 D$ cultures differently. In several tissue culture systems, TGF 1 stimulates the production of fibronectin (Fn) and collagens $(16,52,53)$. Since previous (49) and current studies from our laboratory indicate that RFCs in 3D cultures were no longer sensitive to the anti-proliferative effects of TGF $\beta 1$, we investigated possible differences in TGF $\beta 1$ effects on matrix production, focusing specifically on Fn protein levels. RFCs grown in $2 \mathrm{D}$ cultures exhibited a $1.35 \pm 0.14$-fold increase in Fn protein, when treated with TGF $\beta 1$ for $24 \mathrm{~h}$ and a $3.35 \pm 0.85$-fold increase in Fn protein after 5 -d treatment $(P<0.006$ for $24 \mathrm{~h}$ vs. 5 d) (Fig. 1). In contrast, in 3D cultures, TGFB1 treatment for 24 hours increased Fn synthesis $2.01 \pm 0.24$-fold. Similarly, $5 \mathrm{~d}$ TGF $\beta 1$-treated cells exhibited a $2.41 \pm 0.01$-fold increase in Fn synthesis compared with untreated cells $(P=0.60$ for $24 \mathrm{~h}$ vs. 


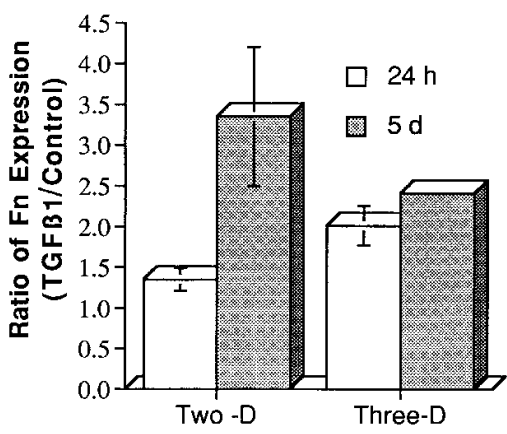

Figure 1. TGF $\beta 1$ modulates Fn protein levels in $2 \mathrm{D}$ and $3 \mathrm{D}$ cultures differently. Graphical representation of densitometry obtained from autoradiographs of affinity-purified $\left[{ }^{35} \mathrm{~S}\right] \mathrm{me}$ thionine labeled Fn from RFCs grown in 2D and $3 \mathrm{D}$ cultures for 1 and $5 \mathrm{~d}$ in the absence and presence of $0.5 \mathrm{ng} /$ $\mathrm{ml}$ TGF $\beta 1$. The data are means \pm SD from three replicate samples/ condition and similar effects were found in two separate studies.

$5 \mathrm{~d}$ ) (Fig. 1). Thus, both in 2D and 3D cultures, TGFß1 treatment increased Fn protein synthesis.

$T G F \beta 1$ increases urokinase plasminogen activator and plasminogen activator inhibitor-1 enzymatic activities in $3 D$ cultures and not in $2 D$ cultures. Previous studies by Pepper and Montesano (8) indicated the importance of protease/protease inhibitor activities during angiogenesis. Therefore, we investigated whether TGF $\beta 1$ modulated the levels of urokinase plasminogen (uPA) and its inhibitor, plasminogen activator inhibitor 1 (PAI-1) during in vitro angiogenesis. RFCs grown in 2D culture for $1 \mathrm{~d}$ exhibited robust uPA activity that decreased over $5 \mathrm{~d}$, and TGF 31 did not appear to affect uPA activity appreciably at either time point. Similarly, there was no significant increase in PAI-1 activity with TGF $\beta 1$ treatment at both time points (Fig. $2 A$ ). In contrast, cells grown in 3D cultures (Fig. $2 \mathrm{~B}$ ) exhibited a different response to TGF31. RFCs freshly mixed in type I collagen for 1 hour exhibited no appreciable uPA activity, although this increased with 1 day of culture, at which time TGF 1 treatment significantly enhanced uPA activity. After $5 \mathrm{~d}$ in culture, uPA activity declined to the levels noted on day one. PAI-1 activity of RFCs freshly mixed in type I collagen gels was high and decreased with $24 \mathrm{~h}$ of culture. However TGF $\beta 1$ enhanced PAI-1 activity compared to control cells at the 1-d time point. At the 5-d time point, both control and TGF $\beta 1$ treated cells exhibited low PAI-1 levels which were not affected by TGF- $\beta 1$ treatment (Fig. $2 B$ ). Hence in contrast to the relative lack of TGF- $\beta 1$ effect on uPA and PAI- 1 in 2D culture, in 3D cultures, there was a concomitant increase in uPA and PAI-1 activities induced by TGF $\beta 1$ at $24 \mathrm{~h}$ after treatment. This could be an important early event in the in vitro angiogenesis assay system we have developed. In this regard, regulated uPA activity could optimize RFC migration which is necessary for aggregation and tube formation.

Matrix organization modulates the expression of TGF $\beta$ receptors in microvessel endothelial cells. The data obtained thus far indicate that TGF $\beta 1$ does not affect the proliferation rates of RFCs grown in 3D collagen gels. Nonetheless, TGF 1 treatment alters both matrix and protease/protease inhibitor protein levels, albeit with distinct patterns of protein and activity profiles compared with RFCs grown in 2D culture. Recent evidence $(38,39)$ suggests that different TGF $\beta$ receptors might regulate different activities induced by TGF $\beta 1$. Specifically, the TGF $\beta$ type II receptor may be involved primarily in regulating DNA synthesis whereas the type I receptor may be involved primarily in matrix synthesis or degradation $(38-40,54$, $55)$. To investigate possible differences in the TGF $\beta$ receptor expression in 2D and 3D cultures, two approaches were taken:

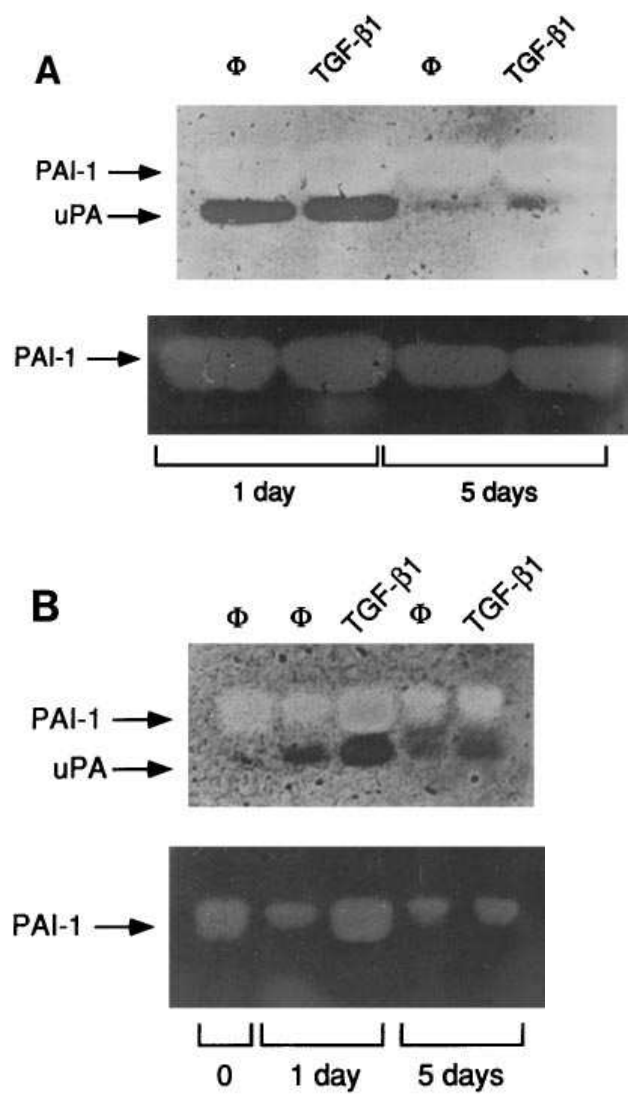

Figure 2. TGF $\beta 1$ modulates uPA and PAI-1 enzymatic activities in 2D and 3D cultures differently. UPA and PAI-1 activities were determined by zymography and reverse zymography, respectively. The data are a representative of three separate studies. (A, upper panel) Zymography of equal amounts of protein lysates from RFCs grown in $2 \mathrm{D}$ culture on coatings of type I collagen for one and five days in the absence $(\Phi)$ and presence of $0.5 \mathrm{ng} / \mathrm{ml}$ TGF $\beta 1$ demonstrating uPA and PAI-1 activities. $u P A$, urokinase type plasminogen activator; $P A I-1$, plasminogen activator inhibitor-1. (Lower panel) Reverse zymography of equal amounts of protein lysates from RFCs grown in $2 \mathrm{D}$ culture on coatings of type I collagen for one and $5 \mathrm{~d}$ in the absence $(\Phi)$ and presence of $0.5 \mathrm{ng} / \mathrm{ml}$ TGF $\beta 1$ demonstrating PAI-1 activities. PAI-1, plasminogen activator inhibitor-1. (B, upper panel) Zymography of equal amounts of protein lysates from RFCs grown in $3 \mathrm{D}$ culture in collagen type I gels for 1 hour, one and five days in the absence $(\Phi)$ and presence of $0.5 \mathrm{ng} / \mathrm{ml}$ TGF $\beta 1$ demonstrating uPA and PAI-1 activities. $u P A$, urokinase type plasminogen activator; $P A I-1$, plasminogen activator inhibitor-1. (Lower panel) Reverse zymography of equal amounts of protein lysates from RFCs grown in 3D culture in collagen type I gels for $1 \mathrm{~h}, 1$ and $5 \mathrm{~d}$ in the absence $(\Phi)$ and presence of $0.5 \mathrm{ng} / \mathrm{ml}$ TGF $\beta 1$ demonstrating PAI-1 activities. $P A I-1$, plasminogen activator inhibitor-1.

analysis of receptor binding using radiolabeled TGF $\beta 1$ and analysis of the surface levels of the type I and type II TGF $\beta$ receptors using specific antisera in a western blotting assay. Saturation binding studies using radio-iodinated and unlabeled ligand with RFCs grown in 2D cultures demonstrated a maximal receptor number of $10,200 \pm 700$ per cell. When radioligand binding was further examined by chemical cross-linking and autoradiography, a complex cell surface profile comprising predominantly TGF $\beta$ types III, II and I receptors was observed. Cells in 2D cultures exhibited appreciable amounts of 
type III and type II receptor and relatively lower levels of type I receptor (Fig. 3 A). Freshly trypsinized cells lose surface expression of these receptors which then reappear after $4 \mathrm{~h}$ (data not shown). Similar experiments with cells grown in 3D cultures gave surprising results. First, there was a significant loss of type III and type II receptor surface expression but low levels of the type I receptor were maintained (Fig. $3 A$ ). The TGF $\beta$ type II receptor to type I receptor ratio in cells grown in 2D cultures compared to cells grown in 3D cultures changed from 5.5 $\pm 0.95: 1$ to $1.1 \pm 0.33: 1(P<0.0001)$ (Fig. $3 B)$. This profile was similar in control and TGF $\beta 1$-treated cells and did not change with $5 \mathrm{~d}$ of culture (data not shown). Hence, reorganization of RFCs in 3D cultures resulted in the loss of surface expression of TGF $\beta$ type III and type II receptors. In order to confirm the results from the ${ }^{125}$ I-TGF $\beta 1$ cross-linking studies, we visualized the type I and II TGF $\beta$ receptors using specific antisera directed against the types I and II receptors in Western blots. Fig. $3 C$ illustrates the expression of type I and type II TGF $\beta$ receptors in lysates of RFCs using specific antisera directed against the type I (right lane) and type II (left lane) receptors (Fig. $3 C$ ). Lysates derived from $2 \mathrm{D}$ and $3 \mathrm{D}$ cultures express type I receptors at approximately the same levels (a $0.2 \pm 0.1$ fold increase in type I receptor expression in $3 \mathrm{D}$ versus $2 \mathrm{D}$ culture, $P=0.11, n=4)$. In contrast, lysates derived from $3 \mathrm{D}$ cultures were noted to exhibit markedly reduced levels of the type II receptor compared to lysates derived from $2 \mathrm{D}$ cultures $(5.73 \pm 2$-fold reduction in type II receptor expression in $3 \mathrm{D}$ cultures compared to $2 \mathrm{D}$ cultures, $P=0.03, n=4)($ Fig. $3 D)$.
Expression of the truncated form of the type II receptor in $R F C$ s results in loss of inhibitory action of TGF 3 in $2 D$ proliferation assays. Our studies showed that the anti-proliferative effect of TGF $\beta 1$ on RFCs in 3D cultures was associated with the loss of surface expression of the TGF $\beta$ type II and type III receptors. Therefore, we decided to determine if expression of a dominant negative mutant form of the type II TGF $\beta$ receptor in RFCs in 2D cultures would render them resistant to the anti-proliferative effects of TGFß. Expression of a type II receptor mutated in the kinase domain, but not in the ligand binding domain would out-compete binding of TGF $\beta 1$ to the normal type II receptor, thus reducing signaling via the type II receptor. To do so, TGF $\beta$ type II receptor truncated within the kinase domain (39) was transfected into RFCs, and stable transfectants were generated by selection with G418. Two clones, type IIT1 and type IIT3, were selected for further analysis. Surface expression of the receptors was assessed by chemical cross-linking with iodinated TGF 1 followed by SDS-PAGE. A representative clone of RFCs expressing the truncated form of the type II receptor is shown in Fig. 4. In addition, the intact and truncated forms of the TGF $\beta$ type I receptor were transfected into RFCs, and stable transfectants were generated. Two clones, ALK54 and ALK58, expressing the type I receptor and three clones, ALK5D1, ALK5D3 and ALK5D4, expressing the truncated form of the type I receptor (33), were analyzed by radioligand binding. The right panel of Fig. 4 shows an autoradiograph of representative clones of RFCs overexpressing the intact type I receptor and RFCs expressing truncated type I and type II receptors. RFCs overex-
A

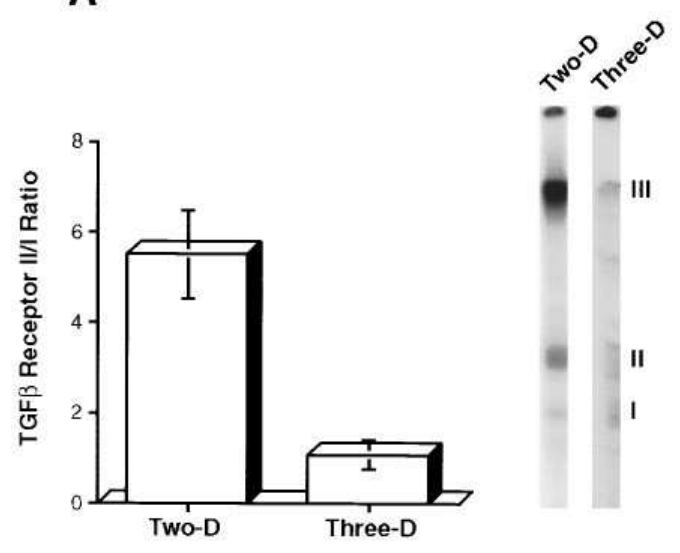

C

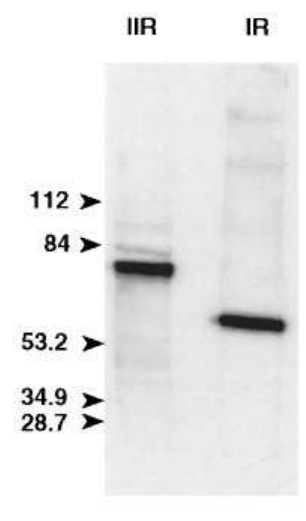

D

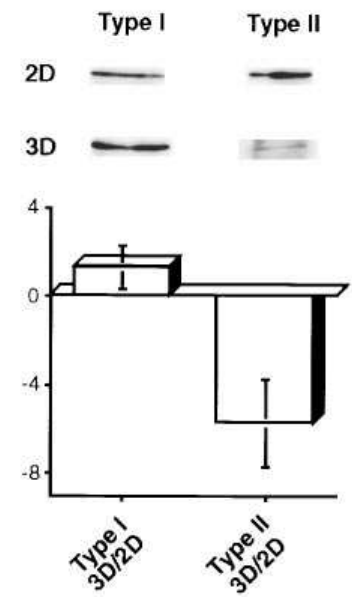

Figure 3. Matrix organization modulates the expression of TGFb receptors in microvessel endothelial cells. RFCs grown in 2D culture (RFC 2D) on coatings of collagen type I and RFCs grown in 3D culture (RFC 3D) in type I collagen gels for $24 \mathrm{~h}$ were chemically cross-linked to 100 $\mathrm{pM}^{125}$ I-TGF $\beta 1$ followed by analysis by SDS-PAGE and autoradiography as described in Methods. Results were obtained from four separate studies. (A) TGF $\beta$ receptor type II:type I ratios determined from densitometry of iodinated TGF $\beta 1$ bound to type I and type II receptors in autoradiographs obtained from RFCs grown in $2 \mathrm{D}$ cultures and $3 \mathrm{D}$ cultures for $24 \mathrm{~h}$. The data are means \pm SD from four separate studies. $(P<$ 0.0001). (B) Representative autoradiograph illustrating type III, II, and I TGF $\beta$ receptors expressed on the surfaces of RFCs grown in 2D culture $($ Two-D) and 3D cultures (Three-D). RFCs grown in 2D culture (RFC 2D) on coatings of collagen type I and RFCs grown in 3D culture (RFC 3D) in type I collagen gels for $24 \mathrm{~h}$ were lysed, followed by analysis by SDS-PAGE and Western blotting using antibodies directed against the type I and type II TGFb receptors as described in Methods. Results were obtained from four separate studies. (C) Representative Western blot of an RFC lysate illustrating the expression of both type II (IIR) and type I (IR) TGF $\beta$ receptors. (D) Relative changes in type I and type II TGF $\beta$ receptor expression in RFC grown in $2 \mathrm{D}$ culture and $3 \mathrm{D}$ culture for $5 \mathrm{~d}$. The data are means \pm SD from four separate studies. (Change in type I receptor 3D vs. 2D $P=0.11$; Change in type II receptor 3D vs. 2D $P<0.03$ ). Representative Western blots illustrating the decrease in type II receptor expression in 3D culture are presented in the upper portion of this figure. 
pressing the type I receptor (designated as IOE) showed a twofold increase in the surface expression of the type I receptor compared to RFCs transfected with the empty vector. In addition, RFCs expressing the truncated forms of the type I (designated IT) and type II (designated IIT) receptors respectively, exhibited reduced surface expression of the type I and type II receptors compared to transfected with vector alone. More importantly, the proportions of TGF $\beta 1$ binding between type II and type I receptors was significantly altered by transfection with the various receptor constructs. The left panel of Fig. 4 shows a graphical representation of densitometry carried out on at least two clones from each set of transfectants to determine the ratios of the type II to type I receptors. As indicated in the graph, the ratio of the type II to type I TGF $\beta$ receptors changed from 3.61 $\pm 0.33: 1$ in vector-control cells to 1.61 $\pm 0.34: 1(P<0.000001)$ in transfectants overexpressing the type I receptor. In transfectants containing the truncated forms of the type I and type II receptors, the ratios changed to 2.60 $0.76: 1(P<0.01)$ and 1.92 $\pm 0.06: 1(P<0.0001)$, respectively.

Proliferation studies with RFCs grown in 2D cultures expressing a truncated type II receptor showed that they were resistant to TGF $\beta 1$ action, by comparison to cells transfected with intact vector or truncated type I receptor (Fig. $5 A$ ). Furthermore, RFCs transfected with truncated type I receptor did not exhibit increased Fn protein synthesis after TGF 31 treatment, although Fn protein synthesis increased in TGFß1treated cells transfected with vector, intact type I receptor, or

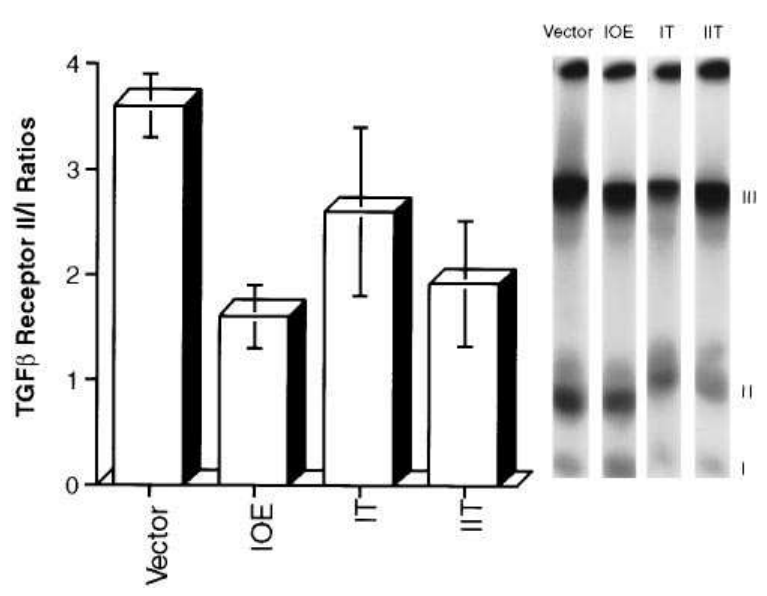

Figure 4. TGF $\beta$ receptor profiles of stable RFC transfectants chemically cross-linked to iodinated TGF $\beta 1$. ( $A$ ) Equal numbers of RFC transfectants expressing the vector (Vector), intact type I receptor (IOE), or truncated forms of the type I (IT) and type II (II T) receptors, respectively, were grown on coatings of type I collagen and chemically cross-linked to $100 \mathrm{pM}$ of [ $\left.{ }^{125 I}\right] \mathrm{TGF} \beta 1$ followed by SDSPAGE and autoradiography as described in Methods. (Right panel) Autoradiograph showing a representative clone from each set of transfectants. (Left panel) Densitometry of iodinated TGF $\beta 1$ bound to type I and type II receptors in autoradiographs obtained from RFC transfectants in 2D cultures plated for $24 \mathrm{~h}$. Three clones each of vector-alone transfectants (V2, V4, V8) and two clones each of ALK5 (ALK54, ALK58), ALK5D transfectants (ALK5D3, ALK5D4) and type IIRT transfectants (typeIIRT1, typeIIRT3) were analyzed. The change in the ratios of the TGF $\beta$ type II/type I are statistically significant between the vector control versus the IOE $(P<0.000001)$, vector versus IT $(P<0.01)$, vector versus IIT $(P<0.0001)$ and IOE versus IT $(P<0.03)(n=4)$. truncated type II receptor. Fig. $5 B$ shows the densitometry obtained from autoradiographs of biosynthetically-labeled affinity-purified Fn from RFC transfectants with and without TGF $\beta 1$ treatment for $24 \mathrm{~h}$. The relative increase in Fn protein levels changed from $3.54 \pm 0.84$ in vector control cells to $1.13 \pm 0.25(P<0.03)$ in transfectants containing the truncated form of the type I receptor and to $3.2 \pm 1.10(P<0.854)$ in transfectants expressing the full length type I receptor. Although cells transfected with truncated type II receptor showed less of an increase in Fn production in response to TGF $\beta 1$ (1.8 \pm 0.21 fold) in comparison to vector-transfected cells $(3.54 \pm 0.84$ fold $)$, this difference was not statistically significant $(P<0.11)$ (Fig. $5 B)$.

Similar effects on Fn levels occurred when transfected RFCs were cultured in 3D, i.e., expression of truncated type I TGF $\beta$ receptor prevented the stimulatory effect of TGF $\beta$ on Fn protein levels. The increase in Fn protein in RFCs expressing the truncated form of type I receptor was $0.8 \pm 0.7$ compared to $1.9 \pm 0.83(P<0.001)$ in vector-control RFCs (Fig. 6). Notably, RFCs expressing the truncated form type II receptor exhibited a $6.0 \pm 2.1$-fold induction of Fn protein compared to a $1.9 \pm 0.83$-fold induction in vector-control RFCs $(P<0.0001)$ (Fig. 6).

Transfection of RFCs with a type III receptor construct in the antisense orientation results in a decrease of endogenous type III receptor expression and blunting of the inhibitory action of TGF 32 in $2 D$ proliferation assays. To further investigate the effect of decreased expression of the type III receptor in RFC noted following institution of 3D culture (Fig. $3 B$ ) we assessed whether transfection of an antisense construct of the type III TGF $\beta$ receptor in RFCs in $2 \mathrm{D}$ cultures would render them more resistant to the anti-proliferative effects of TGF 32 . As illustrated in Fig. 7, RFC transfected with the type III receptor antisense construct express less type III receptor on their surfaces compared to vector alone transfected cells as determined by ${ }^{125}$ I-TGF $\beta$ cross-linking studies (Fig. 7, upper panel). No appreciable changes in the expression of type I or type II receptors were noted (data not shown). Further, when assessed using proliferation assays in 2D culture, the cells transfected with the antisense construct exhibited an unchanged inhibition profile in response to TGF $\beta 1$ but markedly decreased sensitivity to TGF 32 compared with control cells (Fig. 7, lower panel).

\section{Discussion}

Angiogenesis plays a central role in development, repair and tumor growth (1). Although many studies have been performed in 2D culture systems (56), investigating microvascular endothelial cell behavior in 3D culture systems may allow for in vitro conditions that will more closely mimic the in vivo environment. In this paper, we provide evidence for the downregulation of the TGF $\beta$ type III and type II receptor surface expression during angiogenesis when RFCs are grown in 3D cultures. Previous data from our laboratory (43) reported a similar downregulation of the surface expression of the platelet-derived growth factor (PDGF) receptor $\alpha$ and $\beta$ chains in RFCs during in vitro angiogenesis. Recent studies have demonstrated changes in TGF $\beta$ receptor profiles during development, aging and hormone stimulation in a variety of tissues (57-62). These findings are very similar to our results in rat osteoblast-like cell cultures, where a marked decrease in type II 

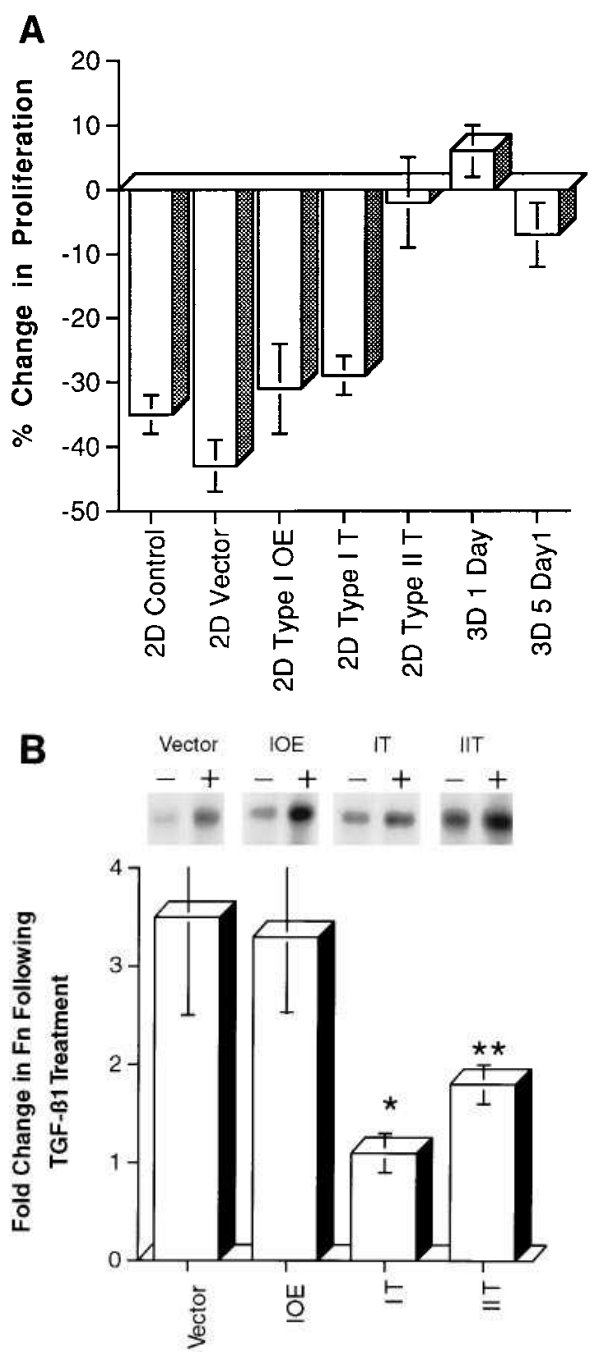

Figure 5. (A) Expression of the truncated form of the type II receptor but not the type I receptor in RFCs results in loss of inhibitory action of TGF $\beta$ in $2 \mathrm{D}$ proliferation assays. Proliferation assays as described in Methods were performed on: control RFC (Control); RFC stably transfected with the neomycin resistance gene - "mock" transfected ( $2 D$ Vector); RFC stably expressing a dominant negative truncation mutant of the type II TGF $\beta$ receptor ( $2 D$ type II T); RFC stably expressing a dominant negative truncation mutant of the type I TGF $\beta$ receptor (2D type I T); RFC stably over-expressing intact type I TGF $\beta$ receptor ( $2 D$ type I $O E$ ) grown for five days in $2 \mathrm{D}$ culture on coatings of collagen type I; RFC grown in $3 \mathrm{D}$ culture in collagen type I gels for one day $(3 D 1 D a y)$; and RFC grown in 3D culture in collagen type I gels for five days (3D 5 Day). Counts were performed on quadruplicate samples. The data are means \pm SD of at least two representative clones from each set of transfectants and were obtained from two separate studies. (B) Expression of the truncated form of the type I receptor but not truncated type II receptor in RFCs results in loss of responsiveness to TGF $\beta 1$ in terms of Fn protein levels. (Upper panel) Autoradiograph of affinity-purified $\left.{ }^{35} \mathrm{~S}\right]$ methioninelabeled Fn from untreated and TGF $\beta 1$ treated cells. Cells were from RFCs containing the vector alone (Vector); RFCs stably transfected with intact type I receptor ( $I O E)$; RFCs stably transfected with a dominant negative truncation mutant of the type I receptor (IT) and RFCs stably transfected with a dominant negative truncation mutant of the type II receptor (II T). The autoradiograph shows the results obtained from a representative clone from each set of transfectants. (Lower panel) A Densitometry obtained from autoradiographs of affinity-purified $\left[{ }^{35} \mathrm{~S}\right]$ methionine-labeled $\mathrm{Fn}$ from RFC transfectants

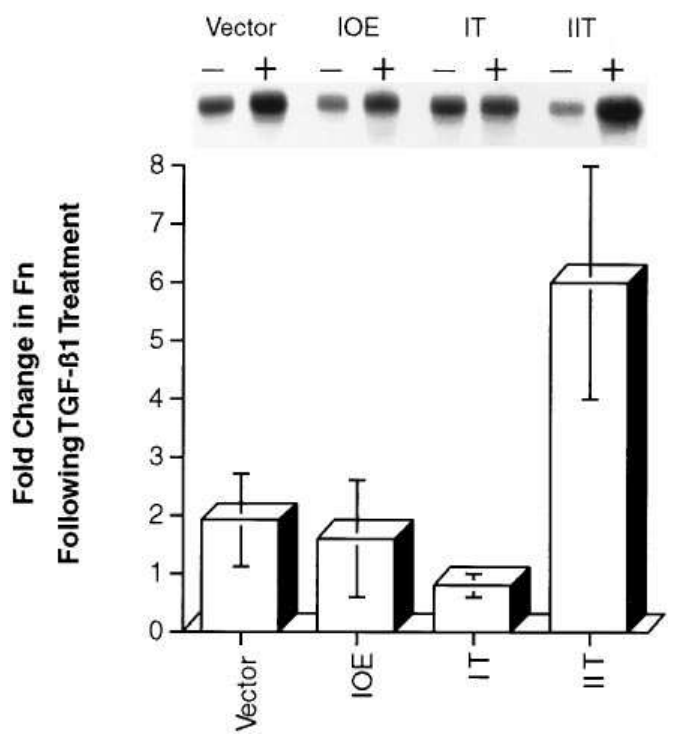

Figure 6. Expression of the truncated form of the type I receptor but not truncated type II receptor in RFCs grown in 3D cultures results in loss of responsiveness to TGF $\beta 1$ in terms of Fn protein levels in RFCs. (Upper panel) Autoradiograph of affinity-purified $\left[{ }^{35} \mathrm{~S}\right] \mathrm{me}$ thionine labeled Fn from untreated and TGF $\beta 1$-treated cells. Equal numbers of cells were grown in 3D culture and were from RFCs containing vector-alone (Vector); RFCs stably transfected with wild-type type I receptor $(I O E)$; RFCs stably transfected with a dominant negative truncation mutant of the type I receptor (IT); and RFCs stably transfected with a dominant negative mutant of the type II receptor (IIT). The autoradiograph shows the results obtained from a representative clone from each set of transfectants. (Lower panel) Densitometry obtained from autoradiographs of affinity-purified $\left[{ }^{35} \mathrm{~S}\right] \mathrm{me}$ thionine-labeled Fn from RFC transfectants grown in 3D cultures treated with/without $0.5 \mathrm{ng} / \mathrm{ml} \mathrm{TGF} \beta 1$ for $24 \mathrm{~h}$. The relative change in Fn protein following TGF $\beta 1$ treatment is statistically significant between vector versus IT $(P<0.0004)$, vector versus IIT $(P<0.0001)$ and IT versus IIT $\left(P<1.87 \times 10^{-6}\right)$. The data are a representative of two replicate samples condition and were obtained from at least two clones from each set of transfectants. Similar effects were found in two separate experiments.

and type III TGF $\beta$ receptors and a relative increase in type I TGF $\beta$ receptors, parallel native and growth factor-induced expression of differentiated cell function. Loss of TGF $\beta$ binding to type II receptors corresponds to a decrease in TGF $\beta$-dependent effects on proliferation, while an increase in TGF $\beta$ binding to type I receptors results in greater levels of type I collagen synthesis and alkaline phosphatase activity (38).

At this time, the molecular mechanism as to how the extracellular matrix can control the cells' responsiveness to soluble growth factors and switch endothelial cells between growth and differentiation is not well understood. We suggest that one of the ways in which extracellular matrix organization modu-

grown in 2D cultures on coatings of collagen type I treated with/without $0.5 \mathrm{ng} / \mathrm{ml}$ TGF $\beta 1$ for $24 \mathrm{~h}$. The relative change in Fn protein after TGF $\beta 1$ treatment is statistically significant between the vector versus IT $(P<0.03)$ and IT versus IIT $(P<0.01)$. The data are a representative of two replicate samples/condition and were obtained from at least two clones from each set of transfectants. Similar effects were found in two separate experiments. 


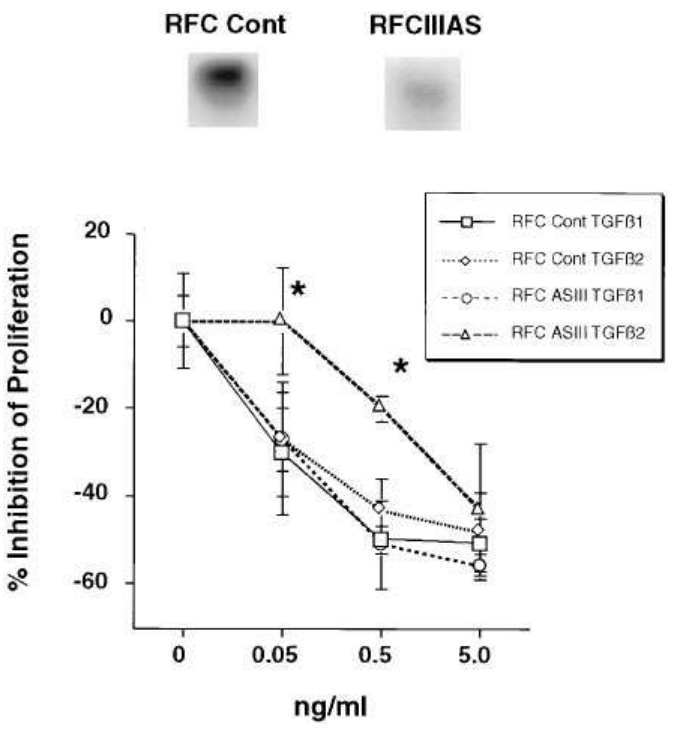

Figure 7. Transfection of RFCs with a type III receptor construct in the antisense orientation results in a decrease of endogenous type III receptor expression and blunting of the inhibitory action of TGF $\beta 2$ in $2 \mathrm{D}$ proliferation assays. (Upper panel) Equal numbers of RFC transfectants expressing the vector (Vector) or an antisense construct of the type III receptor (IIIAS), respectively, were grown on coatings of type I collagen and chemically cross-linked to $100 \mathrm{pM}$ of $\left[{ }^{125} \mathrm{I}\right] \mathrm{TGF} \beta 1$ followed by SDS-PAGE and autoradiography as described in Methods. Autoradiograph showing a representative clone from each set of transfectants. Note the decreased intensity of the type III receptor in the clone containing the IIIAS construct. (Lower panel) Proliferation assays of control cultures of RFC (squares and diamonds) and RFC transfected with an antisense construct of the type III TGF $\beta$ receptor (circles and triangles) in the presence of TGF $\beta 1$ (squares and circles) or TGFß2 (diamonds and triangles). $n=3 ; * P<0.02$.

lates the behavior of microvessel endothelial cells is by regulating the surface expression of receptors to growth factors, as we have shown for both PDGF and TGF $\beta$ receptors. Several investigators have provided evidence for the importance of cell-matrix interactions in the formation of capillary tubes by microvessel endothelial cells $(11,14,49,63)$. Hence the interaction of the cells with the matrix is an important component of microvessel endothelial cell differentiation and angiogenesis. To address this question, we compared the TGF 1 responsiveness of RFCs grown in 2D versus 3D cultures. Notably, the cells grown in $3 \mathrm{D}$ cultures were resistant to the anti-proliferative response by TGF $\beta 1$ compared to cells grown in 2D cultures. However TGF $\beta 1$ was still able to modulate the expression of matrix molecules such as fibronectin in both 2D and 3D cultures, albeit with different protein synthetic patterns and activity profiles, depending upon the culture conditions. Although in 2D cultures there was no profound modulation of either uPA or PAI-1 levels, in 3D cultures, there was a concomitant increase in both uPA and PAI-1 activities early during the in vitro angiogenic process. Previous data indicated that TGF $\beta 1$ upregulates PAI-1 levels and downregulates uPA levels $(22,64)$. Most of these studies, however, were carried out using large vessel endothelial cells in 2D cultures. The concomitant increase in both uPA and PAI-1 activities 24 hours after addition of TGF $\beta 1$ treatment may indicate recycling of the UPA receptor since the $\mathrm{uPA}$ receptor bound to the uPA-
PAI-1 complex causes internalization and recycling to a new surface to which uPA can bind and activate proteolysis. The current hypothesis is that high levels of PAI-1 may be needed to cause a constant change of uPA receptor position $(65,66)$; a situation that is likely to occur during tumor spreading and metastasis and during angiogenesis.

Our results suggest that the downregulation of the surface expression of the TGF $\beta$ type II receptor in the microvessel cells grown in $3 \mathrm{D}$ cultures led to their resistance to the antiproliferative effects of TGF $\beta 1$. Yet these cells were still able to respond to TGF $\beta 1$ in terms of elevated matrix production, such as fibronectin, as well as protease/protease inhibitor activities, such as uPA and PAI-1. Thus, the results suggest different signaling pathways mediate TGF $\beta 1$-induced growth inhibition and stimulation of extracellular matrix production in the microvessel endothelial cells. These findings are summarized in Table 1. We suggest that the change in the ratios of the surface expression of the TGF $\beta$ type II to type I receptors in $2 \mathrm{D}$ versus $3 \mathrm{D}$ cultures may modulate the cells' responsiveness to TGF $\beta$. There have also been several previous reports that support different signaling pathways for growth inhibition and matrix production $(39,54)$. In complementation analyses using different cell hybrids, increased type II receptor expression was associated with growth suppression but not the induction of several matrix proteins (55). When the truncated form of the type II receptor was overexpressed in mink lung cells, the cells became resistant to the antiproliferative effect of TGF $\beta$ and were unable to maintain the retinoblastoma protein in the hypophosphorylated state and yet the induction of plasminogen activator type I (PAI-1) and fibronectin synthesis by TGF $\beta$ was unaffected (39). In addition, 293 cells, which lack detectable levels of the type II receptor and are not responsive to the antiproliferative activity of TGF $\beta$, but have type I receptor and display a TGF $\beta$-induced synthesis of fibronectin (67). Also, chemically mutagenized bovine endothelial cells express a resistant phenotype that was found to be a glycosylation defect in the type II receptor. Although the growth inhibition response to TGF $\beta$ was completely lost, the activation of fibronectin and plasminogen activator inhibitor-1 by TGF $\beta$ still occurred (68). Hence, there appear to be at least two distinct receptor-associated signaling pathways for the type I and type II receptors; each mediating a separate set of TGF $\beta$ activ-

Table I. Responsiveness of Microvascular Endothelial Cells to TGF 31 when Cultured on a Coating of Type I Collagen (2D) or in a Three-Dimensional Collagen Gel (3D): Correlation with TGF $\beta$ Receptor Surface Expression

\begin{tabular}{lcccccc}
\hline & \multicolumn{2}{c}{$2 \mathrm{D}$} & & \multicolumn{2}{c}{$3 \mathrm{D}$} \\
\cline { 2 - 3 } \cline { 5 - 6 }+ TGFß1 & $1 \mathrm{~d}$ & $5 \mathrm{~d}$ & & $1 \mathrm{~d}$ & $5 \mathrm{~d}$ \\
\hline Proliferation & Dec. & Dec. & & No $\Delta$ & No $\Delta$ \\
Fn Synthesis & + & +++ & & ++ & ++ \\
uPA Activity & No $\Delta$ & No $\Delta$ & & ++ & No $\Delta$ \\
PAI Activity & No $\Delta$ & No $\Delta$ & & ++ & No $\Delta$ \\
Type I Receptor & & No $\Delta$ & & No $\Delta$ \\
Type II Receptor & & No $\Delta$ & & Dec. \\
II/I Ratio & & 5.0 & & 1.0 \\
& & & & & \\
\hline
\end{tabular}

Dec., decrease; Inc., increase; $\Delta$, change.,,,$++++++++++=$ minimal, modest, moderate, and maximal increases, respectively. 
ities. Differences between our results in endothelial cells (this report) and in bone cells (38) both mesenchymal tissuederived, and those obtained with mink lung epithelial cell cultures (37), may relate to tissue or embryonic cell lineage variations. Alternately, our studies are performed with low passage or primary cell isolates, while studies that exhibit type I and type II TGF $\beta$ receptor co-dependence were performed in continuously cultured cells or in cells previously mutated with a chemical carcinogen. Therefore, different or interrupted downstream signalling events may predominate in one or another tissue culture model.

The data obtained from our stable RFC transfectants expressing the truncated form of the TGF $\beta$ type II receptor further substantiates our hypothesis. When functional type II receptor surface expression was reduced in these cells by expressing a dominant negative mutant, the cells became resistant to the anti-proliferative effects of TGF 31 in 2D cultures, thus mimicking the situation of these cells in 3D cultures. The effect appears to be specific since RFCs overexpressing the TGF $\beta$ type I receptor and a truncated form of the type I receptor maintained their anti-proliferative response to TGF $\beta 1$. Additionally, RFCs overexpressing the truncated TGF $\beta$ type I receptor became less responsive to TGF $\beta 1$ in terms of increase in Fn protein synthesis, further suggesting different signaling pathways for proliferation response versus extracellular matrix synthesis responses. Consistent with these findings, similar effects on Fn levels were obtained when RFC transfectants containing the truncated form of the type I receptor were examined in 3D cultures. Notably, 3D cultures of RFCs transfected with truncated type II receptor expressed even greater levels of Fn in response to TGF $\beta 1$ than similar cultures of cells transfected with the vector alone. One likely explanation may be that cells in $3 \mathrm{D}$ culture endogenously down regulate relative surface expression of the type II TGF $\beta$ receptor, and thus signal predominantly through type I receptors. This result is even further enhanced when these cells express a dominant negative type II receptor. Within this context, the ratio of functional ligand binding is further skewed to the type I receptor, accentuating effects that may signal predominantly through type I receptor complexes. Our transfected cultures exhibit a phenotype consistent with the changes in the expression of intact or truncated TGF $\beta$ receptors. Changes in receptor ratios and downstream events in response to TGF $\beta 1$ in the transfected cultures are summarized in Table II.

Similar to our findings noted with the type II and type I truncated receptor expression, the data obtained from our stable RFC transfectants expressing an antisense construct of the TGF $\beta$ type III receptor further substantiates our hypothesis that changes in receptor expression determines, in part, the cellular responsiveness to particular growth factor isoforms. Specifically, the decrease of type III receptor expression (a TGF $\beta$ binding protein thought to mediate the binding and presentation of TGF $\beta 2$ to the type II receptor in large vessel endothelial cells) (44) elicited the selective loss of the inhibitory effect of TGF 32 on RFC proliferation, while eliciting no change in the inhibitory effect of TGF $\beta 1$ on RFC proliferation.

In conclusion, we have provided evidence that matrix-organization mediated changes in microvascular cell differentiation parallel changes in the surface expression of the cells' TGF $\beta$ receptors and modification of the cells' responsiveness to TGF $\beta 1$. The findings that selective expression of dominant negative mutants of the type I and type II receptors and anti-
Table II. Responsiveness to TGF $\beta 1$ of Microvascular Endothelial Cells Over-expressing Type I TGF $\beta$ Receptor (IOE), a Kinase Negative Type I TGF Receptor (IT), a Kinase Negative Type II TGFß Receptor (IIT) and Empty Vector $(\Phi)$ : Correlation of Proliferative and Fibronectin Synthetic Activities with Receptor Expression

\begin{tabular}{lcccc}
\hline \multicolumn{1}{c}{ + TGF $\beta 1$} & $\Phi$ & IOE & IT & IIT \\
\hline II/I receptor ratio & $3.6 \pm 0.3$ & $1.6 \pm 0.3$ & $2.6 \pm 0.3$ & $1.9 \pm 0.3$ \\
2D Prolif. & Inhib. & Inhib. & Inhib. & No $\Delta$ \\
2D Fn & Inc. & Inc. & No $\Delta$ & Inc. \\
3D Fn & Inc. & Inc. & No $\Delta$ & Inc. \\
& & & & \\
\hline
\end{tabular}

Inc., increase; Inhib., inhibited; $\Delta$, change.

sense constructs of the type III receptor specifically affect TGF $\beta$ mediated extracellular matrix synthetic or proliferative events respectively lend support to this concept. The data presented here and previous work from our laboratory and others showing modulation of PDGF and TGF $\beta$ receptors in endothelial cells is consistent with our concept that microvessel endothelial cells exhibit a "plastic" phenotype, displaying a variety of phenotypes in response to changes in the local extracellular matrix and soluble factor environments as observed in vitro and in vivo during angiogenesis (1, 41, 43, 49, 69). This ability of microvascular endothelial cells may be important for microvessel endothelial cells to differentially respond to specific cues from the environment such as release of growth factors and changes in the matrix composition and organization that occur during growth, development and wound healing.

\section{Acknowledgments}

We thank Joanne Lum, Sandra Casinghino, Adeline Tucker and Dr. Anne Romanic for expert technical assistance and advice. We are also indebted to David Johnson for critically reading this manuscript.

This work was supported by the Reed Foundation Fellowship in Vascular biology (S. Sankar), United States Public Health Service grants RO-1HL28373 and PO-1DK38979 (J.A. Madri), RO1 AR39201 (M. Centrella), BRSG/RR-05358 (M. Centrella, T. McCarthy) and American Heart Association grant No. 92006500 (J.A. Madri).

\section{References}

1. Madri, J.A., and M. Marx. 1992. Matrix composition, organization and soluble factors: modulators of microvascular cell differentiation in vitro. Kidney Int. 41:560-565.

2. Madri, J.A., S. Sankar, and A.M. Romanic. 1995. Angiogenesis. In The Molecular and Cellular Biology of Wound Healing. Plenum, NY. In press.

3. Montesano, R., J.D. Vassali, A. Baird, R. Guillemin, and L. Orci. 1986. Basic fibroblast growth factor induces angiogenesis in vitro. Proc. Natl. Acad. Sci. USA. 83:7297-7301.

4. Burgess, W.H., and T. Maciag. 1986. The heparin-binding (fibroblast) growth factor family of proteins. Annu. Rev. Biochem. 58:575-606.

5. Millauer, B., S. Wizigmann-Vousi, H. Schnurch, R. Martinez, N.P.H. Muller, W. Risau, and A. Ullrich. 1993. High affinity VEGF binding, and development expression suggest Flk-1 as a major regulator of vasculogenesis and angiogenesis. Cell. 72:835-946.

6. Muller, G., J. Behrens, U. Nussbaumer, P. Bohlen, and W. Birchmeier. 1987. Inhibitory effect of transforming growth factor $\beta$ on endothelial cells. Proc. Natl. Acad. Sci. USA. 84:5600-5604.

7. Roberts, A.B., M.B. Sporn, R.K. Assoian, J.M. Smith, W.S. Roche, L.A. Wakefield, U.I. Heine, L. A. Liotta, V. Falanga, J.H. Kehl, and A.S. Fauci. 1986. Transforming growth factor $\beta$ : rapid induction of fibrosis and angiogene- 
sis in vivo and stimulation of collagen formation in vitro. Proc. Natl. Acad. Sci. USA. 83:4167-4171.

8. Pepper, M.S., and R. Montesano. 1990. Proteolytic balance and capillary morphogenesis. Cell Differ. Dev. 32:319-328.

9. Montesano, R., and L. Orci. 1985. Tumor-promoting phorbol esters induce angiogenesis in vitro. Cell. 42:469-477.

10. Madri, J.A., and S. K. Williams. 1983. Capillary endothelial cell cultures: phenotypic modulation by matrix components. J. Cell Biol. 97:153-165.

11. Madri, J.A., B.M. Pratt, and A.M. Tucker. 1988. Phenotypic modulation of endothelial cells by transforming growth factor $\beta$ depends upon the composition and organization of the extracellular matrix. J. Cell Biol. 106:1375-1384.

12. Nicosia, R.F., and J.A. Madri. 1987. The microvascular extracellular matrix: developmental changes in the aortic ring-plasma clot model. Am. J. Pathol. 128:78-90.

13. Ingber, D., and J. Folkman. 1989. How does extracellular matrix control capillary morphogenesis. Cell. 58:803-85.

14. Gamble, J.R., L.J. Matthias, G. Meyer, P. Kain, G. Russ, R. Faull, M.C. Berndt, and M.A. Vadas. 1993. Regulation of in vitro capillary tube formation by anti-integrin antibodies. J. Cell Biol. 121:931-943.

15. Lyons, R.M., and H.L. Moses. 1990. Transforming growth factor $\beta$ and the regulation of cell proliferation. Eur. J. Biochem. 187(3):467-473.

16. Roberts, A.B., and M.B. Sporn. 1990. The transforming growth factor $\beta$ 's. In Peptide Growth Factors and Their Receptors. Springer-Verlag, Berlin. 419-472.

17. Massague, J. 1990. The transforming growth factor- $\beta$ family. Annu. Rev. Cell Biol. 6:597-641.

18. Kingsley, D.M. 1994. The TGF- $\beta$ Superfamily: new members, new receptors, and new genetic tests of function in different organisms. Genes \& Dev. 8:133-146.

19. Edwards, D.R., G. Murphy, J.J. Reynolds, S.E. Whitman, A.J.P. Docherty, P. Angel, and J.K. Heath. 1987. Transforming growth factor beta modulates the expression of collagenase and metalloproteinase inhibitor. EMBO (Eur. Mol. Biol. Organ.) J. 6:1899-1906.

20. Overall, C., J.L. Wrana, and J. Sodek. 1989. Independent regulation of collagenase, $72 \mathrm{kDa}$ progelatinase, and metalloendoproteinase inhibitor (TIMP) expression in human fibroblasts by transforming growth factor- $\beta . J$. Biol. Chem. 204:1860-1869.

21. Matrisian, L.M., D. Lerob, C. Ruhlmann, M.C. Gesnel, and R. Breathnach. 1986. Isolation of the oncogene and epidermal growth factor induced transin gene: complex control in rat fibroblasts. Mol. Cell Biol. 6:1679-1686.

22. Saksela, O., D. Moscatelli, and D.B. Rifkin. 1987. The opposing effects of basic fibroblast growth factor and TGF- $\beta 1$ on the regulation of plasminogen activator activity in capillary endothelial cells. J. Cell Biol. 105:957-963.

23. Laiho, M., O. Saskela, and J. Keski-Oja. 1987. Transforming growth factor- $\beta$ induction of type 1 plasminogen activator inhibitor. J. Biol. Chem. 262: $17467-17474$.

24. Mustoe, T.A., G.F. Pierce, A. Thomason, P. Gramates, M.B. Sporn, and T.F. Deuel. 1987. Transforming growth factor beta induces accelerated healing of incisional wounds in rats. Science 237:1333-1336.

25. Yang, E.Y., and H.L. Moses. 1990. Transforming growth factor $\beta-1$ Induced changes in cell migration, proliferation, and angiogenesis in the chicken chorioallantoic membrane. J. Cell Biol. 111:731-741.

26. Merwin, J.R., W. Newman, L.D. Beall, A. Tucker, and J.A. Madri. 1991. Vascular cells respond differently to transforming growth factors $\beta 1$ and $\beta 2$ in vitro. Am. J. Pathol. 138:37-51.

27. Madri, J.A., L. Bell, M. Marx, J.R. Merwin, C.T. Basson, and C. Prinz. 1991. The effects of soluble factors and extracellular matrix components on vascular cell behaviour in vitro and in vivo: models of de-endothelialization and repair. J. Cell. Biochem. 45:1-8.

28. Massague, J. 1992. Receptors for the TGF $\beta$ Family. Cell. 69:1067-1070.

29. Lin, H.Y., and H.F. Lodish. 1993. Receptors for the TGF- $\beta$ Superfamily: multiple polypeptides and serine/threonine kinases. Trends Cell Biol. 3:14-19.

30. Miyazano, K., P. ten Dijke, H. Ichijo, and C.H. Holdin. 1994. Receptors for transforming growth factor $\beta$. Adv. in Immunology. 55:181-220.

31. Cheifetz, S., H. Hernandez, M. Laiho, P. ten Dijke, K.K. Iwata, and J. Massague. 1991. Distinct transforming growth factor- $\beta$ receptor subsets as determinants of cellular responsiveness to three TGF- $\beta$ isoforms. J. Biol. Chem. 265:20533-20538.

32. Segarini, P.R., D.M. Rosen, and S.M. Seyedin. 1989. Binding of TGF- $\beta$ to cell surface proteins varies with cell type. Mol. Endocrinol. 3:261-272.

33. Franzen, P., P. ten Dijke, H. Ichijo, H. Yamashita, P. Schultz, C.H. Heldin, and K. Miyazono. 1993. Identification of a TGF $\beta$ type I receptor as a novel member of the serine/threonine kinase receptor family. Cell. 75:681-692.

34. Lin, H.Y., X.-F. Wang, N.-E. E., R.A. Weinberg, and H.F. Lodish. 1992. Expression cloning of the TGF $\beta$ type II receptor, a functional transmembrane serine/threonine kinase. Cell. 68:775-785.

35. Laiho, M., F. M.B. Weiss, and J. Massague. 1990. Concomitant loss of transforming growth factor- $\beta$ receptor types I and II in cell mutants resistant to TGF- $\beta$. J. Biol. Chem. 265:18518-18524.

36. Wrana, J.L., L. Attisano, J. Carcamo, A. Zentella, J. Doody, M. Laiho, X.-F. Wang, and J. Massague. 1992. TGF- $\beta$ signals through a heteromeric protein kinase receptor complex. Cell. 71:1003-1014.
37. Wrana, J.L., L. Attisano, R.K. Wieser, F. Ventura, and J. Massague. 1994. Mechanism of activation of the TGF- $\beta$ receptor. Nature (Lond.). 370:341347.

38. Centrella, M., J. Kim, T. Pham, S. Casinghino, V. Rosen, J. Wozney, and T.L. McCarthy. 1995. Independent changes in type I and type II receptors for transforming growth factor $\beta$ induced by bone morphogenetic protein-2 parallel expression of the osteoblast phenotype. Mol. Cell. Biol. 15:3273-3281.

39. Chen, R.H., R. Ebner, and R. Derynk. 1993. Inactivation of the type II receptor reveals two receptor pathways for the diverse TGF- $\beta$ activities. Science (Wash. DC). 260:1335-1338.

40. Derynck, R. 1994. TGF $\beta$-receptor mediated signalling. Trends Biochem. Sci. 19:548-553.

41. Kocher, O., and J.A. Madri. 1989. Modulation of actin mRNAs in cultured capillary endothelial and aortic endothelial and smooth muscle cells by matrix components and TGF-31. In Vitro. 25:424-434.

42. Merwin, J.R., J.M. Anderson, O. Kocher, C.M.V. Itallie, and J.A. Madri. 1990. Transforming growth factor beta modulates extracellular matrix organization and cell-cell junctional complex formation during in vitro angiogenesis. J. Cell Physiol. 142:117-128.

43. Marx, M., R. Perlmutter, and J.A. Madri. 1994. Modulation of PDGF receptor expression in microvascular endothelial cells during in vitro angiogenesis. J. Clin. Invest. 93:131-139.

44. Sankar, S., N. Mahooti-Brooks, M.Centrella, T.L. McCarthy, and J.A Madri.1995. Expression of trasnsforming growth factor type III receptor in vascular endothelial cells increases their responsiveness to transforming growth factor $\beta 2$. J. Biol Chem. 270:13567-13572.

45. Madri, J.A., and H. Furthmayr. 1980. Collagen polymorphism in the lung: an immunochemical study of pulmonary fibrosis. Hum. Path. 11:353-366.

46 Roll, F.J., J.A. Madri, J. Albert, and J. Furthmayr. 1980. Co-distribution of collagen types IV and AB2 in basement membranes and mesangium of the kidney. J. Cell Biol. 85:597-616.

47. Chomczynski, P., and N. Sacchi. 1987. Single step method of RNA isolation by acid guanidium thiocyanate phenol-chloroform extraction. Anal. Biochem. 162:156-159.

48. Romanic, A.M., and J.A. Madri. 1994. Extracellular matrix degrading proteinases in the nervous system. Brain Pathol. 4 (2):145-156.

49. Madri, J.A., L. Bell, and J.R. Merwin. 1992. Modulation of vascular cell behaviour by transforming growth factors beta. Mol. Rep. Dev. 32:121-126.

50. Centrella, M., T.L. McCarthy, and E. Canalis. 1988. Parathyroid hormone modulates transforming growth factor $\beta$ activity and binding in osteoblastic cells. Proc. Natl. Acad. Sci. USA. 85:5889-5893.

51. Laemmli, U.K. 1970. Cleavage of structural proteins during the assembly of the head of bacteriophage T4. Nature (Lond.). 227:680-685.

52. Ignotz, R.A., and J. Massague. 1986. Transforming growth factor beta stimulates the expression of fibronectin and collagen and their incorporation into the extracellular matrix. J. Biol. Chem. 261(9):4337-4345.

53. Varga, J., and S.A. Jimenez. 1986. Stimulation of normal human fibroblast collagen production, and processing by transforming growth factor beta. Biochem. Biophy. Res. Commun. 138(2):976-980.

54. Franzen, P., H. Ichijo and K. Miyazono. 1993. Different signals mediate transforming growth factor- $\beta 1$-induced growth inhibition and extracellular matrix production in prostate carcinoma cells. Exp. Cell Res. 207:1-7.

55. Geiser, A.G., J.K. Burmester, R. Webbink, A.B. Roberts, and M.B. Sporn. 1992. Inhibition of growth by transforming growth factor $\beta$ following fusion of two non- responsive human carcinoma cell lines; implications of the type II receptor in growth inhibitory responses. J. Biol. Chem. 267:2588-2593.

56. Lobb, R., J. Sasse, R. Sullivan, Y. Shing, P. D'Amore, J. Jacobs, and M. Klagsbrun. 1986. Purification and characterization of heparin-binding endothelial growth factors. J. Biol. Chem. 261 (4):1924-1928.

57. Centrella, M., S. Casinghino, R. Ignotz, and T.L. McCarthy. 1992. Multiple regulatory effects by transforming growth factor- $\beta$ on type I collagen levels in osteoblast enriched cultures from fetal rat bone. Endocrinology. 131:28632872

58. Cochet, C., J.J. Feige, and E.M. Chambaz. 1988. Bovine adrenocortical cells transforming growth factor $\beta$ receptors which are regulated by adrenocorticotropin. J. Biol. Chem. 263:5707-5713.

59. Hu, J.S., and E.N. Olsen. 1990. Functional receptors for transforming growth factor $\beta$ are retained by biochemically differentiated $\mathrm{C} 2$ myocytes in growth factor deficient medium containing EGTA, but down-regulated during terminal differentiation. J. Biol. Chem. 265:7914-7919.

60. Centrella, M., T.L. McCarthy, and E. Canalis. 1991. Glucorcorticoid regulation of transforming growth factor b1 (TGF-b1) activity and binding in osteoblast-enriched cultures from fetal rat bone. Mol. Cell Biol. 11:4490-4496.

61. Ewton, D.Z., G. Spizz, E.N. Olson, and J.R. Florini. 1988. Decrease in transforming growth factor- $\beta$ binding and action during differentiation in muscle cells. J. Biol. Chem. 263:4029-4032.

62. Friedman, S.L., G. Yamasaki, and L. Wong. 1994. Modulation of transforming growth factor $\beta$ receptors of rat lipocytes during hepatic wound healing response. J. Biol. Chem. 269:10551-10558.

63. Grant, D.S., K.I. Iashiro, B. Segui-Real, Y. Yamada, G.R. Martin, and H.K. Kleiman. 1989. Two different laminin domains mediate the differentiation of human endothelial cells into capillary-like structures in vitro. Cell. 58:933-943. 
64. Pepper, M.S., D. Belin, R. Montesano, L. Orci, and J.D. Vassali. 1990. Transforming growth factor $\beta-1$ modulates basic fibroblast growth factorinduced proteolytic and angiogenic properties of endothelial cells in vitro. $J$. Cell. Biol. 111:743-755.

65. Vassali, J.D., A.P. Sappino, and D. Belin. 1991. The plasminogen activator/plasmin system. J. Clin. Invest. 88:1067-1072.

66. Blasi, F. 1993. Urokinase, and urokinase receptor: a paracrine/autocrine system regulating cell migration and invasiveness. BioEssays. 15:105-111.

67. Arrick, B.A., A.R. Lopez, F. Elfman, R. Ebner, C.H. Damsky, and R. Derynck. 1992. Altered metabolic and adhesive properties and increased tu- morigenesis associated with increased expression of transforming growth factor beta 1. J. Cell Biol. 118:715-726.

68. Fafeur, V.B., I. Terman, J. Blum, and P. Bohlen. 1990. Basic FGF treatment of endothelial cells downregulates the $85 \mathrm{kDa}$ TGF beta receptor subtype and decreases the growth inhibitory response to TGF-beta 1. Growth Factors. 3 237-245.

69. Battegay, E.J., J. Rupp, L. Iruela-Arispe, E.H. Sage, and M. Pech. 1944. PDGF-BB modulates endothelial proliferation and angiogenesis in vitro via PDGF beta-receptors. J. Cell Biol. 1254:917-928. 